\title{
HUBUNGAN SELEKSI JALUR MASUK PENERIMAAN MAHASISWA BARU DENGAN INDEKS PRESTASI KUMULATIF (IPK) PADA MAHASISWA FAKULTAS KEDOKTERAN UNIVERSITAS PALANGKA RAYA
}

\author{
Jurean Triabdi ${ }^{1}$, Francisca Diana Alexandra² ${ }^{2}$ dan Helena Jelita ${ }^{3}$ \\ 1. Fakultas Kedokteran Universitas Palangka Raya, Palangka Raya, Kalimantan Tengah \\ 2. Departemen Farmakologi Fakultas Kedokteran Universitas Palangka Raya, Palangka \\ Raya, Kalimantan Tengah \\ 3. Departemen Gigi dan Mulut Fakultas Kedokteran Universitas Palangka Raya, Palangka \\ Raya, Kalimantan Tengah \\ Email : jureantriabdi@gmail.com
}

\begin{abstract}
ABSTRAK
Latar belakang : Prestasi belajar selalu dihubungkan dengan hasil belajar seorang mahasiswa. Prestasi belajar mahasiswa menjadi salah satu tolak ukur keberhasilan mutu perguruan tinggi. Prestasi belajar mahasiswa dapat ditunjukkan oleh skor indeks prestasi kumulatif (IPK) yang diperoleh masing-masing mahasiswa.

Tujuan : Penelitian ini bertujuan untuk mengetahui hubungan seleksi jalur masuk penerimaan mahasiswa baru dengan indeks prestasi kumulatif (IPK) pada mahasiswa tahun pertama Fakultas Kedokteran Universitas Palangka Raya.

Metode Penelitian : Jenis penelitian yang digunakan adalah analitik kuantitatif dengan menggunakan rancangan penelitian cross sectional. Teknik pengambilan sampel pada penelitian ini adalah Total Sampling, populasi pada penelitian ini menggunakan sampel data jalur masuk seleksi mahasiswa Fakultas Kedokteran Universitas Palangka Raya, jalur SNMPTN, SBMPTN, dan SMMPTN angkatan tahun 2019 yang berjumlah 101 sampel data. Analisis penelitian ini menggunakan Uji statistic dengan koefisien gamma (BxK) dengan nilai sigifikan 95\% menggunakan program komputer.

Hasil : Hasil penelitian tidak menunjukan adanya hubungan antara seleksi jalur penerimaan mahasiswa baru dengan indeks prestasi kumulatif (IPK) dengn nilai $p=0,427$ serta nilai korelasi 0,142 menunjukan korelasi negatif dengan kekuatan lemah.

Kesimpulan : Tidak terdapat hubungan eantara seleksi jalur penerimaan mahasiswa baru dengan indeks prestasi kumulatif (IPK) pada mahasiswa Fakultas Kedokteran Universitas Palangka Raya angkatan tahun 2019.
\end{abstract}

Kata Kunci : Jalur masuk penerimaan, mahasiswa kedokteran, indeks prestasi kumulatif 
E-ISSN 2723-5890

\title{
RELATIONSHIP OF NEW STUDENT ADMISSION PATH SELECTION WITH CUMULATIVE ACHIEVEMENT INDEX (GPA) IN STUDENTS OF THE FACULTY OF MEDICINE UNIVERISTY PALANGKA RAYA
}

\begin{abstract}
ABSTRAC
Background: Learning achievement is always related to the learning outcome of the college student. Learning achievement is one of the benchmarks for the success of higher education quality in college. The cumulative average score (GPA) of students shows learning achievement. The selection of the entrance route is one way to select students who can continue their studies at universities, especially at the Faculty of Medicine.

Purpose: This research study aims to determine the relationship between admission pathway selection and the cumulative grade point average (GPA) of the first-year college student of the Faculty of Medicine, University Palangka Raya.

Methodology: This type of research is quantitative analytic, using a cross-sectional research design. Total sampling was the sampling technique used. The population in the study is the entry route for the selection of students from the Faculty of Medicine, University of Palangka Raya, including SNMPTN, SBMPTN, SMMPTN batch 2019 with 99 students. The analysis for this study uses a statistical test with a gamma coefficient with a practical computer program of $95 \%$.

Result: The research study did not show a relationship between new college student admission $(p=0,427)$ with the cumulative grade point average (GPA). The correlation value 0,142 indicates a negative correlation with weak correlation strength.

Conclusion: There is no relationship between the selection of new college student admissions pathways and the cumulative grade point average (GPA) to college student Faculty of Medicine, University Palangka Raya 2019.
\end{abstract}

Key Word: admission pathway, medical student, cumulative grade point 


\section{PENDAHULUAN}

Prestasi belajar selalu dihubungkan dengan hasil belajar seorang mahasiswa. Prestasi belajar mahasiswa menjadi salah satu tolak ukur keberhasilan mutu perguruan tinggi. Prestasi belajar mahasiswa dapat ditunjukkan oleh skor indeks prestasi kumulatif (IPK) yang diperoleh masingmasing mahasiswa. Indeks Prestasi Kumulatif (IPK) dapat digunakan sebagai indikator mengukur keberhasilan proses belajar mengajar prestasi belajar mahasiswa, setiap mahasiswa tentunya pasti mengharapkan Indeks Kumulatif Prestasi bisa mendapatkan nilai sempurna yaitu 4,0. Indeks Kumulatif Prestasi (IPK) mahasiswa tentunya memiliki harapan bagi setiap Universitas karena tinggi rendahnya IPK mahasiswa mencerminkan kualitas Universitas.

Faktor yang mempengaruhi prestasi belajar secara garis besar dapat dikelompokkan menjadi beberapa hal, yaitu; Faktor internal dan faktor eksternal, faktor internal ini sering disebut faktor instrinsik yang meliputi kondisi fisiologi dan kondisi psikologis yang mencakup minat, kecerdasan, bakat, motivasi, sedangkan faktor eksternal, faktor ini sering disebut dengan faktor ekstrinsik yang meliputi segala sesuatu yang berasal dari luar diri individu yang dapat mempengaruhi prestasi belajarnya baik itu di lingkungan sosial maupun lingkungan lain ${ }^{1}$

Miarso mengemukakan kerangka teori pembelajaran yang dapat dilihat pada gambar dibawah yaitu pembelajaran tersusun atas beberapa komponen yaitu pertama kondisi pembelajaran yang terdiri dari karakteritik siswa dan karakteristik pelajaran. Karakteristik pelajaran terbagia dua yaitu tujuan dan hambatan. Menentukan tujuan pembelajaran merupakan komponen utama yang harus terlebih dulu dirumuskan dalam proses pembelajaran karena berfungsi sebagai indikator keberhasilan pembelajar. Peranan tujuan ini sangat penting, karena merupakan sasaran dari proses pembelajaran. Tujauan ini pada dasarnyan merupakan rumusan prilaku dan kemampuan yang harus dicapai dan dimiliki siswa setelah ia menyelesaikan kegiatan belajar dalam proses pembelajaran. Komponen yang kedua dalah pemilihan metode pembelajaran yang didalamnya terdapat kegiatan mengorganisasikan bahan pembelajaran, menentukan strategi pembelajaran, memilih metode dan alat pembelajaran serta pengelolaan kegiatan. Komponen ketiga yang terakhir adalah menetapkan kriteria keberhasilan proses pembelajaran dari evaluasi yang dilakukan ${ }^{2}$.

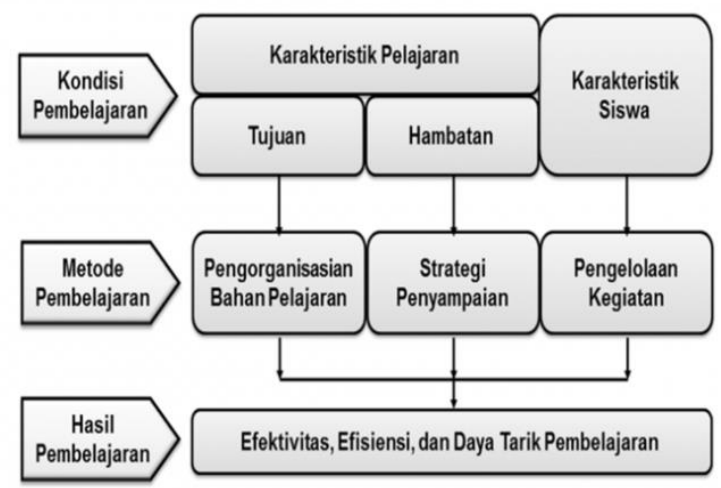

Gambar 1. Kerangka Teori Pembelajaran

Masalah mengenai IPK dapat ditemukan pada mahasiswa baru masuk dunia perkuliahan, hal ini dikarenakan penyesuaian diri terhadap sistem baru pada mahasiswa di tahun pertama sering sulit mereka dilakukan. Perbedaan proses belajar mengajar dan kurikulum dibandingkan saat di SMA merupakan salah satu faktornya. Tahun awal perkuliahan menjadi penentu bagi mahasiswa baru karena dapat mempengaruhi kesuksesan dalam mengikuti kegiatan akademik, sehingga di tahun awal inilah mereka membangun pengetahuan dasar, kepercayaan diri, dan komitmen belajar. Beberapa penlitian menunjukkan hasil akademik pertama dapat memprediksi hasil akademik lebih lanjut pada materi dengan kesulitan yang semakin tinggi. Setiap Perguruan Tinggi Negeri (PTN) terutama di Indonesia untuk dapat masuk dan dapat belajar memiliki beberapa jalur seleksi masuk.

Fakultas Kedokteran Univeritas Palangka Raya sejak tahun 2015 setiap tahun melakukan penerimaan siswa baru melalui tiga jalur, yang pertama adalah lewat jalur Seleksi Nasional Masuk Perguruan Tinggi Negeri (SNMPTN) atau lebih dikenal sebagai jalur undangan, dilakukan berdasarkan hasil penelusuran prestasi akademik dengan menggunakan rapor dan portofolio akademik. Rapor yang digunakan adalah semester satu sampai dengan semester lima bagi Sekolah Menengah Atas, Sekolah Menengah Kejuruan, Madrasah Aliah (SMA/SMK/MA) dengan masa belajar tiga tahun atau semester satu sampai dengan semester tujuh bagi SMK dengan masa belajar empat tahun ${ }^{3}$, kedua jalur Seleksi Bersama Masuk Perguruan Tinggi (SBMPTN) adalah jalur yang kedua setelah siswa tidak berhasil lolos dari SNMPTN, yaitu jalur yang membantu perguruan tinggi untuk memperoleh calon 
mahasiswa yang diprediksi mampu menyelesaikan studi di perguruan tinggi berdasarkan nilai akademik dan/atau prestasi siswa lainnya ${ }^{4}$, dan ketiga jalur Seleksi Mandiri Masuk Perguruan Tinggi Negeri Wilayah Barat (SMMPTN Wilayah Barat) adalah jalur mandiri yang dilaksanakan Universitas itu sendiri, dimana seleksinya berdasar hasil Ujian Tulis Berbasis Cetak (UTBC) atau kombinasi hasil ujian tulis dan data portofolio serta ujian lainnya yang dilakukan secara bersama ${ }^{5}$ Mahasiswa yang lulus pastilah siswa yang berkompeten, karena Fakultas Kedokteran Universitas Palangka Raya pastinya menginginkan lulusan yang bermutu, kompeten, berdaya saing, dan berbudi pekerti. Oleh karena terdapat karakteristik yang berbeda dari setiap jalur masuk maka akan berpotensi pada pencapaian IPK yang juga berbeda sehingga penelitian ini bertujuan untuk melihat apakah ada hubungan antara seleksi jalur masuk penerimaan mahasiswa baru dengan Indeks Prestasi Kumulatif (IPK) di tahun pertama.

\section{METODE PENELITIAN}

Jenis penelitian yang digunakan adalah kuantitatif yang bersifat analitik dengan metode cross sectional. Penelitian ini dilakukan di Fakultas Kedokteran Universitas Palangkaraya pada tahun 2020, populasi pada penelitian ini adalah mahasiswa angkatan 2019 Fakultas Kedokteran Universitas Palangkaraya yang mendaftar masuk melalui jalur seleksi SNMPTN, SBMPTN, dan SMMPTN Wilayah Barat dengan total sebanyak 99 orang mahasiswa. Teknik pengambilan sampel pada penelitian ini adalah Total Sampling yaitu teknik sampling yang digunakan oleh peneliti dengan mengambil seluruh sampel yang ada dengan jumlah 99 mahasiswa yang terdaftar, bedasarkan kriteria inklusi dan ekslusi jumlah total sampel data sebanyak 99 data mahasiswa angkatan 2019. Variabel bebas pada penelitian ini adalah seleksi jalur masuk penermiaan mahasiswa baru, sedangkan variable terikatnya adalah IPK. Untuk variabel seleksi jalur penerimaan dikategorikan berdasarkan nilai standar Fakultas dengan ketentuan sebagai berikut :

$$
\begin{array}{ll}
\text { IPK Memuaskan } & 2,00-2,75 \\
\text { IPK Sangat memuaskan } & 2,76-3,50 \\
\text { IPK Cumlaude } & >3,50
\end{array}
$$

Analisis ini digunakan untuk mengetahui kemaknaan hubungan antara variabel bebas dan variabel terikat. Uji yang digunakan dalam penelitian ini adalah Uji Korelasi Koefisien Gamma $\left(\begin{array}{lll}B & x & K\end{array}\right)$ karena variabel datanya ordinal dan setiap kelompok terdiri dari tiga kelompok

\section{HASIL PENELITIAN DAN PEMBAHASAN}

Pengambilan data menggunakan data sekunder, yaitu data akademik di program studi pendidikan dokter Fakultas Kedokteran Universitas Palangka Raya. Jumlah mahasiswa saat penelitian hanya 99 mahasiswa.

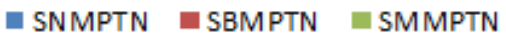

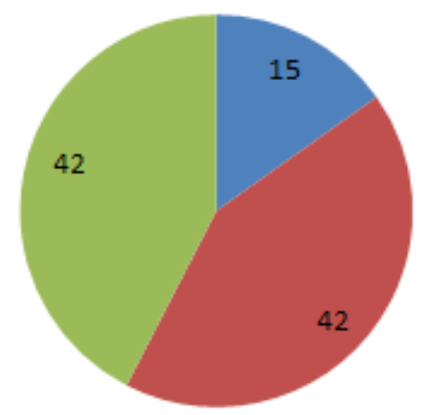

Gambar 1. Gambaran jalur masuk penerimaan mahasiswa FK UPR

Berdasarkan gambar 1 diatas, distribusi frekuensi tingkatan IPK menunjukan bahwa 99 data mahasiswa dimana 15 data dari jalur SNMPTN, 42 data dari jalur SBMPTN, dan 42 data dari SMMPTN.

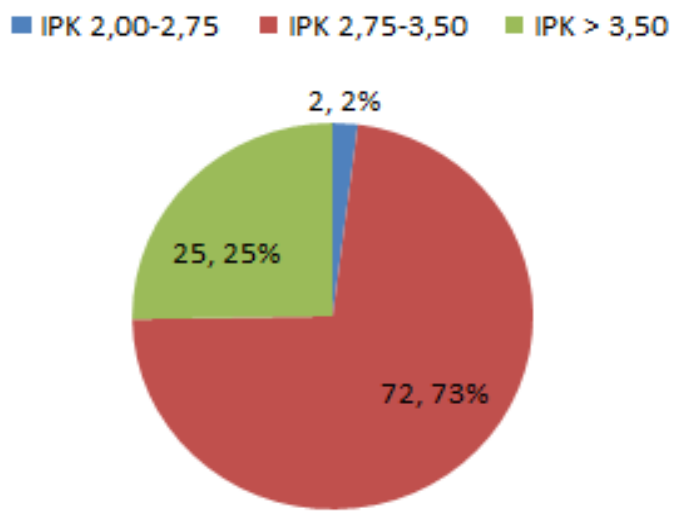

Gambar 2. Gambaran tingkatan IPK mahasiswa angkatan 2019 FK UPR

Gambar 2 menunjukkan berdasarkan hasil seleksi masuk penerimaan jalur masuk IPK mahasiswa Fakultas Kedokteran angkatan 2019 pada tahun pertamanya. Distribusi frekuensi IPK $<2,75$ terdata 1 mahasiswa (50\%) dari SNMPTN dan 1 mahasiswa (50\%) dari SMMPTN, IPK 2,75-3,50 terdata 12 mahasiswa $(16,7 \%)$ dari SNMPTNdan 
terbanyak 34 mahasiswa $(47,2 \%)$ dari SMMPTN, sedangkan IPK > 3,50 terdata hanya 2 mahasiswa $(8,0 \%)$ dari SNMPTN dan terbanyak 16 orang (64\%) dari SBMPTN.

Tabel. 1 Hubungan Antara Variabel

\begin{tabular}{|c|c|c|c|c|c|c|}
\hline & & \multicolumn{3}{|c|}{$\begin{array}{l}\text { Indeks Prestasi } \\
\text { Kumulatif (IPK) }\end{array}$} & \multirow{2}{*}{$\begin{array}{l}\text { Koef } \\
\text { isien } \\
\text { korel } \\
\text { asi } \\
\text { (r) }\end{array}$} & \multirow[b]{2}{*}{$\begin{array}{l}\mathrm{Ni} \\
\text { lai } \\
p\end{array}$} \\
\hline & & $\begin{array}{l}\text { Memu } \\
\text { askan }\end{array}$ & $\begin{array}{l}\text { Sanga } \\
\mathrm{t} \\
\text { Memu } \\
\text { askan }\end{array}$ & $\begin{array}{l}\text { Cum } \\
\text { Lau } \\
\text { de }\end{array}$ & & \\
\hline & & $\begin{array}{l}2,00- \\
2,75\end{array}$ & $\begin{array}{l}2,76- \\
3.50\end{array}$ & $\begin{array}{l}3,51 \\
- \\
4,00\end{array}$ & $\begin{array}{l}0,14 \\
2\end{array}$ & $\begin{array}{l}0, \\
42 \\
7\end{array}$ \\
\hline & $\begin{array}{l}\text { SNM } \\
\text { PTN }\end{array}$ & $\begin{array}{l}1 \\
(50 \%)\end{array}$ & $\begin{array}{l}12 \\
(16,7 \\
\%)\end{array}$ & $\begin{array}{l}2 \\
(8 \% \\
)\end{array}$ & & \\
\hline $\begin{array}{l}\text { Jal } \\
\text { ur } \\
\text { Ma }\end{array}$ & $\begin{array}{l}\text { SBM } \\
\text { PTN }\end{array}$ & 0 & $\begin{array}{l}26 \\
(36,1 \\
\%)\end{array}$ & $\begin{array}{l}16(6 \\
4 \%)\end{array}$ & & \\
\hline SUK & $\begin{array}{l}\text { SM } \\
\text { MPT } \\
\text { N }\end{array}$ & $\begin{array}{l}1 \\
(50 \%)\end{array}$ & $\begin{array}{l}34 \\
(47,2 \\
\%)\end{array}$ & $\begin{array}{l}7 \\
(28 \\
\%)\end{array}$ & & \\
\hline $\begin{array}{l}\text { Tot } \\
\text { al }\end{array}$ & & $\begin{array}{l}2 \\
(100 \% \\
)\end{array}$ & $\begin{array}{l}72 \\
(100 \% \\
)\end{array}$ & $\begin{array}{l}25 \\
(100 \\
\%)\end{array}$ & & \\
\hline
\end{tabular}

Melalui uji statistik dengan kolerasi koefisien gamma ordinal - ordinal didapatkan nilai $p$-value $=0,427$, yang menunjukkan bahwa korelasi antara seleksi penerimaan mahasiswa dengan IPK tidak bermakna. Nilai korelasi sebesar 0,142 menunjukkan korelasi negatif yang mengartikan bahwa ketidak adanya hubungan serta saling berlawanan antara variabel bebas dan variabel terikat.

Pada table 1 memperlihatkan bahwa korelasi antara seleksi penerimaan mahasiswa dengan IPK tidak bermakna, korelasi negatif yang berarti hubungan antara keduanya berlawanan atau tidak sejalan, dapat dilihat dari jalur SBMPTN lebih banyak mahasiswa yang IPK nya > 3,50. Hal ini berbeda dengan penilitian lain yang dilakukan oleh Ade Kiki Riezky tahun 2016 dimana jalur masuk memiliki hubungan dengan IPK $^{6}$, dan juga penelitian yang dilakukan oleh Rizky Rahma Pratami tahun 2014 dimana terdapat hubungan antara jalur penerimaan memiliki hubungan dengan IPK sehingga menyimpulkan sebaiknya PTN untuk menambah kuota penerimaan jalur SNMPTN, sedangkan SBMPTN dan SMMPTN dianjurkan untuk meningkatkan motivasi belajar ${ }^{7}$.
Hasil ini sesuai dengan penelitian yang dilakukan Nurhasanah dan kawan-kawan bahwa tidak ada pengaruh antar IPK mahasiswa dengan Jalur masuk ke universitas namun IPK tergantung pada kemampuan dasar dari mahasiswa sejak SMA, kemauan memilih jurusan pendidikan, kesenangan mereka terhadap bidang yang mereka pilih dan cara belajar mereka ${ }^{8}$.

Indeks Kumulatif Prestasi (IPK) mahasiswa tentunya memiliki harapan bagi setiap Universitas karena tinggi rendahnya IPK mahasiswa mencerminkan kualitas Universitas. Prestasi belajar mahasiswa yang satu dengan yang lainnya tidaklah sama, karena prestasi belajar dipengaruhi oleh beberapa faktor antara lain kemampuan tenaga pendidik, fasilitas, kebiasaan belajar, motivasi belajar, jalur masuk, lingkungan keluarga dan potensi yang ada pada diri mahasiswa sendiri ${ }^{7}$. Penelitian yang dilakukan ini memiliki kelemahan. Kelemahan pada peneilitian ini dikarenakan prestasi belajar mahasiswa lebih dipengaruhi oleh faktor-faktor prestasi belajar lain seperti motivasi, lingkungan belajar, lingkungan keluarga, adapun kelemahan lain dari penelitian ini adalah karena pada sampel penelitian ini hanya menggunakan 1 angkatan saja, kemudian jika dibandingkan dengan penelitian lain, hasil pada penelitian lain tidak berfokus kepada jalur masuk penerimaan melainkan faktor lain yang kuat dalam prestasi belajar mahasiswa serta tingkat kecerdasan berdasarkan tes masuk baik UTBK ataupun TPA.

\section{PENUTUP}

Berdasarkan tujuan dan hasil penelitian mengenai hubungan seleksi penerimaan mahasiswa baru dengan indeks prestasi kumulatif (IPK) pada mahasiswa Fakultas Kedokteran Universitas Palangka Raya maka dapat disimpulkan hasil analisis hubungan seleksi jalur penerimaan mahasiswa baru dengan indeks prestasi kumulatif (IPK) menunjukan bahwa tidak bermakna, karena nilai $\mathrm{p}=0,427$ ( $\mathrm{p}<$ $0,005)$ serta nilai korelasi 0,142 menunjukan korelasi negatif.

\section{DAFTAR PUSTAKA}

1. Mustamin H, Sulasteri S. Faktor-faktor yang mempengaruhi prestasi belajar mahasiswa jurusan pendidikan matematika fakultas tarbiyah dan keguruan uin alauddin makassar. J Mat dan Pembelajaran. 2010;1(1):151-77.

2. Yusufhadi M. Menyemai Benih Teknologi Pendidikan. Jakarta: Kencana; 2007.

3. BKS PTN Barat. Informasi Seleksi Mandiri Masuk Perguruan Tinggi Negeri (SMMPTN) 
Wilayah Barat 2020 [Internet]. Jakarta; Available from: https://smmptnbarat.id/informasi-umum.html

4. Lembaga Tes Masuk Perguruan Tinggi. Informasi UTBK - SBMPTN 2020 ( Ujian Tulis Berbasis Komputer dan Seleksi Bersama Masuk Perguruan Tinggi Negeri. Jakarta;

5. Lembaga Tes Masuk Perguruan Tinggi. Informasi Seleksi Nasional Masuk Perguruan Tinggi Negeri (SNMPTN) 2020 [Internet]. Jakarta; 2020. Available from: https://ltmpt.ac.id/?mid=7

6. Riezky AK. Hubungan Hasil Seleksi Penerimaan Mahasiswa Baru dengan Indeks Prestasi Kumulatif pada Mahasiswa Program Studi Pendidikan Dokter Fakultas Kedokteran Universitas Abulyatama. Seambi Akad. 2016;IV(2):91-5.

7. Pratami RR. Pengaruh Jalur Seleksi Masuk, Lingkungan Keluarga Dan Motivasi Belajar Sebagai Variabel Intervening Terhadap Prestasi Belajar Mahasiswa Jurusan Pendidikan Akuntansi Fakultas Ekonomi Universitas Negeri Semarang Tahun 2014. [Internet]. 2014. Available from: http://lib.unnes.ac.id/id/eprint/21192

8. Nurhasanah, Purwati, Ahmad H. Pengaruh Sistem Seleksi Masuk Perguruan Tinggi Terhadap Indeks Prestasi Mahasiswa Jurusan Pendidikan Matematika Universitas Papua (UNIPA). Pros Semin Nas. 2015;03:114-20. 